\title{
ARTYKUŁY
}

Klio. Czasopismo poświęcone dziejom Polski i powszechnym PL ISSN 1643-8191, t. 41 (2)/2017, s. 129-157

(c) $(1) \Theta$

ANNA WNUK*

\section{Szlachta w testamentach i inwentarzach mieszczan lubelskich z końca XVI i pierwszej połowy XVII wieku}

\section{Nobility in testaments and inventories of Lublin citizens from the end of $16^{\text {th }}$ and the first half of $17^{\text {th }}$ centuries}

Streszczenie: Artykuł ukazuje udział szlachty w życiu Lublina. W wielu testamentach i inwentarzach mieszczan lubelskich z lat 1590-1655 można odnaleźć wzmianki, które są odbiciem więzi łączących przedstawicieli obydwu stanów. Powiązania mieszczańsko-szlacheckie miały najczęściej charakter: finansowy, osobisty i ekonomiczno-zawodowy.

Wpływ na obecność szlachty w Lublinie miało m.in. funkcjonowanie tu od 1578 roku Trybunału Koronnego dla prowincji małopolskiej. Na przełomie XVI i XVII wieku Lublin był dla szlachty miejscem załatwiania spraw urzędowych o charakterze wojewódzkim i powiatowym, ponieważ odbywały się tu sejmiki, sądy ziemskie i grodzkie. Szlachta przyjeżdżała tu ze swoich posiadłości i spędzała nierzadko całe tygodnie w celu załatwienia różnych interesów. Lublin stanowił także główny ośrodek handlowy i największy rynek zbytu płodów rolnych w regionie.

Zgromadzenie w Lublinie tłumów szlachty było dla miasta dość uciążliwe, np. z powodu zajęcia ratusza na sesje trybunalskie, masowego wynajmowania pomieszczeń u miesz-

*Adres email: awnuk18@wp.pl. 
czan. Z drugiej strony wpływało to na rozwój tego ośrodka i aktywizację wytwórczości rzemieślniczej.

Mieszczanie opiekowali się przyjezdnymi w chorobie, zapewniali żywność, a w przypadku śmierci pogrzeb. Bliskie kontakty łączyły szlachtę z patrycjatem lubelskim. Czynnikiem, który sprzyjał silniejszym więziom przedstawicieli obydwu stanów, było też uleganie nowinkom religijnym w okresie reformacji.

Przebywanie szlachty w mieście sprzyjało nawiązaniu bliższych więzi z miejscową społecznością, co mogło zaowocować m.in. pobytem synów mieszczańskich na dworach szlacheckich, udzielaniem im pomocy w edukacji czy w karierze zawodowej. Szlachta poszukiwała w mieście produktów o dużym stopniu przetworzenia, wymagających specyficznych umiejętności, których nie posiadali zatrudnieni niejednokrotnie w folwarkach pracownicy dworscy. Korzystała bardzo często z usług wykwalifikowanych rzemieślników. W XVI wieku w obrębie murów i na przedmieściach powstawały coraz liczniej dwory szlacheckie. Testamenty i inwentarze mieszczan wskazują, że wpływ szlachty na życie miasta w omawianym przełomowym okresie był duży. W XVII wieku zmienił się charakter ośrodka lubelskiego, a sytuacja szlachty i państwa polskiego odbijała się na pozycji mieszczan.

Abstract: The article tells about nobility's participation in Lublin life. There are a lot of testaments and inventories, where we can find some information showing a positive correlation between the representatives of both estates (nobility and burghers). The relationship was based on financial, personal, economic and professional interests.

Crown Tribunal had been in existence since 1578 in Malopolska Province that resulted the appearance of noble landowners there. Lublin was the place to deal with official matters on voivodeship and regional levels because of regional assemblies functioning. Land and municipal courts were also held there.

Noble landowners came here from their mansions and often spent weeks to arrange different things. Lublin was also the main trading centre and the biggest agricultural market in the region. The crowds of noble landowners were too burdensome for the town because of the fact, that town hall was too busy during the tribunal sessions and besides that they rented burgers' premises a lot.

On the other hand it had been influenced the development of the city and activating the crafting creativity. The burgers took care of newcomers in case of illness or death (funeral) or provided them with food. There was close relationship between noble landowners and Lublin patriciate.

The representatives of both estates (nobility and burghers) showed a marked adherence to new religious trends during the Reformation, that was the factor which made the relationship closer between them. The existence of noble landowners in the town contributed to better relations with the local society-the nobles hosted burgers' sons, helped them with education and professional carries.

In the town the noble landowners were looking for high recyclable products demanding high quality skills, which their employed servants didn't posses. They often used highqualified men good with their hands. In $16^{\text {th }}$ century within the walls and town outskirts 
more and more noble manor houses were built. The burghers' testaments and inventories show that the noble influence on town life was very high during that period. In $17^{\text {th }}$ century, the character of Lublin society had changed and the situation with noble and state reflected burghers position.

Słowa kluczowe: Lublin, szlachta, mentalność mieszczan, testamenty i inwentarze, kultura materialna w czasach nowożytnych.

Keywords: Lublin, noble landowners, mentality, burghers, testaments and inventories, material culture in the early modern period.

$\mathrm{W}$

życiu Lublina czynnie uczestniczyli przedstawiciele szlachty, głównie z obszaru województwa lubelskiego. W wielu testamentach i inwentarzach mieszczan lubelskich z lat 1590-1655 można odnaleźć wzmianki, które są odbiciem więzi łączących obydwa stany. Badany materiał źródłowy obejmuje 376 testamentów i 200 inwentarzy. Powiązania mieszczańsko-szlacheckie miały najczęściej charakter: finansowy, osobisty i ekonomiczno-zawodowy. W 1578 roku powstał w Lublinie Trybunał Koronny dla prowincji małopolskiej, która obejmowała także województwa: ruskie, bełskie, podolskie, wołyńskie, bracławskie i kijowskie. Na przełomie XVI i XVII wieku Lublin był dla szlachty miejscem załatwiania spraw urzędowych o charakterze wojewódzkim i powiatowym, ponieważ odbywały się tu sejmiki, sądy ziemskie i grodzkie. Szlachta przyjeżdżała tu ze swoich posiadłości i spędzała nierzadko całe tygodnie w celu załatwienia różnych interesów. Lublin stanowił także główny ośrodek handlowy i największy rynek zbytu płodów rolnych w regionie, dlatego szlachta właśnie tutaj sprzedawała duże ilości zboża i inne produkty ze swoich folwarków ${ }^{1}$. Artykuły te stanowiły m.in. podstawę wyżywienia dla mieszczan, surowiec do produkcji gorzałki i piwa oraz paszę dla koni. Jarmarki lubelskie kwitły jeszcze w drugiej połowie XVI wieku i były magnesem przyciagającym wielu kupujących i sprzedających, m.in. z odległych miast oraz spoza granic Rzeczypospolitej. Jednak stopniowo, już

1 Archiwum Państwowe w Lublinie (dalej APL) Księgi Miasta Lublina (dalej KmL), sygnatura (dalej S.) 139, rok (R.) 1633, Inwentarz (dalej Inw.) Jana Okonia, s. 119. 
od początku XVII stulecia, stawały się przede wszystkim zjazdami krajowymi. Decydował o tym m.in. coraz większy udział szlachty w handlu. Mieszczanie utrzymywali kontakty z nią na różnym podłożu. Wzmianki o tym są w wielu testamentach. Najczęściej wspominają o nich złotnicy (18 przypadków), urzędnicy miejscy (18 przypadków), krawcy (osiem przypadków), kupcy i sprzedawcy (sześć przypadków).

Częste, nawet krótkotrwałe pobyty szlachty w Lublinie wywierały znaczny wpływ na życie miasta. Czasami przyjezdnych z dalszych i bliższych terenów zaskakiwała w Lublinie choroba i tu spisywali swoje testamenty. Asystowali przy tej czynności mieszczanie, w tym urzędnicy, duchowni czy członkowie stanu szlacheckiego ${ }^{2}$. Wysoko urodzeni korzystali z ksiąg miejskich w szczególnych okolicznościach, niejako w zastępstwie ksiąg sądów szlacheckich (15 przypadków) ${ }^{3}$. Decydując się na rezygnację z droższej i bardziej uciążliwej procedury, mieli świadomość mniejszej wagi dowodów z ksiąg miejskich, jednak chwilowo zadowalali się nimi, mając nadzieję na dopełnienie formalności przed sądami właściwymi, czyli grodzkimi i ziemskimi, w terminie późniejszym ${ }^{4}$. Korzystający z usług kancelarii miejskiej wywodzili się raczej z warstwy drobnej szlachty. Zamieszkała w miastach szlachta uwierzytelniała przed sądami miejskimi transakcje czy oświadczenia woli wprowadzające zmiany w istniejącym stanie posiadania i zjawisko takie należy poniekąd uznać za naturalne, zgodne z istniejącym stanem prawnym. Konstytucja sejmowa z 1550 roku zezwalała szlachcie na zakup placów, domów i spichlerzy w miastach 5 .

Szlachta z bliższych i dalszych okolic miasta zjeżdżała do Lublina na sejmiki czy sesje Trybunału, zatrzymując się u mieszczan ${ }^{6}$. W kamienicach były pomieszczenia przeznaczone stale na stancje deputatów trybu-

${ }^{2}$ APL KmL, S. 137, R. 1617, Testament (Test.) Maksymiliana Młodzianowskiego, s. $157-158$.

${ }^{3}$ Por. T. Opas, Miasta szlacheckie województwa lubelskiego w XVIII wieku, Lublin 1966 (maszynopis pracy doktorskiej w Bibliotece Głównej UMCS).

${ }^{4} \mathrm{M}$. Trojanowska, Dokument miejski lubelski od XIV do XVIII wieku. Studium dyplomatyczne, Warszawa 1977, s. 84-85.

${ }^{5} \mathrm{~J}$. Łosowski, Kancelarie miast szlacheckich województwa lubelskiego od XV do XVIII wieku, Lublin 1997, s. 181.

${ }^{6}$ APL KmL, S. 137, R. 1617, Test. Łukasza Begla, s. 152. 
nalskich, w innych zaś zatrzymywali się zainteresowani sesjami Trybunału. Przymus zakwaterowania gości często stanowił duży problem, tym bardziej że szlachetnie urodzeni przebywali razem ze służbą, końmi i bagażami ${ }^{7}$. Od obowiązku użyczania mieszkań nie były wolne nawet patrycjuszowskie siedziby przy Rynku, gdzie najczęściej szukali lokum magnaci i dygnitarze. Pomieszczenia te musiały odpowiadać wymaganiom szacownych gości. Zgodnie z treścią inwentarza szlachcica Marcina Laskowskiego, który przebywał w kamienicy rajcy Jana Reklowskiego, w wielkiej izbie stołowej znalazło się:

5 szpalerów zielonych przybitych na ścianie, 3 nowe kobierce adziamskie słupiaste, 2 kilimy tureckie pstre, a trzeci czerwony, stary kobierzec pod oknem, na ścianie kilim perski nowy, kobierzec na stole, 3 księgi pisane w skórze, tłumok skórzany zamknięty na kłódkę, w którym pełno rzeczy, kobza, beczki wina ${ }^{8}$.

Zjazd szlachty oznaczał nierzadko nagłe podwojenie liczby mieszkańców miasta, ponieważ za panami ciągnęła nie tylko służba, prywatne wojsko, a także kupcy oraz żebracy. Często gospodarze domów byli zmuszeni do opuszczenia własnych mieszkań i przeniesienia się do mniej wygodnych pomieszczeń, np. na poddaszu, w komórce czy w oficynie. Adam Maier skarżył się, że deputaci często zajmowali jego kamienicę przy ulicy Olejnej. Uważał, że fakt ten doprowadził nawet do zrujnowania budynku. Dlatego mieszczanin rozpoczął remont, naprawiając okna, ławy, ustępy ${ }^{9}$.

Zgromadzenie w Lublinie tłumów szlachty i magnatów było dla miasta dość uciążliwe. W ratuszu miały miejsce posiedzenia rady miejskiej i sądu wójtowsko-ławniczego. Tu odbywał swoje sesje również Trybunał Koronny. Ratusz lubelski mieścił ponadto arsenał miejski, archiwum i skarbiec, pomieszczenie dla kancelarii radzieckiej i ławniczej, straży miejskiej. $\mathrm{W}$ podziemiach mieściło się więzienie. W jednej z piwnic pod ratuszem

7 „Konie z siodłami, [...] są na Przedmieściu w gospodzie...”: APL KmL, S. 137, R. 1619, Test. Nobilis Zachariasza Arciszewskiego, s. 295.

8 APL KmL, S. 138, R. 1631, Inw. Marcina Laskowskiego, s. 806-807.

9 Archiwum Archidiecezjalne Lubelskie (dalej AAL), S. Rep. 60 A. 21, R. 1627, Test. Adama Maiera, k. 183v, 184. 
znajdowała się izba tortur ${ }^{10}$. Jednak funkcjonowanie szlacheckich instytucji w mieście (Trybunału Koronnego i sejmików) przyczyniło się do wzrostu znaczenia Lublina w państwie. Przybywali tu liczni przedstawiciele szlachty, aby załatwić m.in. sprawy urzędowe, sądowe, obywatelskie, finansowe, handlowe. Wpływało to na rozwój ośrodka i aktywizację wytwórczości rzemieślniczej, ale też wprowadziło wiele zamętu. Zdarzało się, że szlachta nie chciała słuchać władz miejskich, co z pewnością nie było korzystne dla handlowej roli Lublina ${ }^{11}$. Życie wewnętrzne miasta było podporządkowane rytmowi zjazdów handlowych i szlacheckich.

Działalność Trybunału przynosiła niebagatelne zyski samym mieszczanom. W czasie sesji trybunalskich wzrastało zapotrzebowanie na różnorodne towary i wyroby rzemieślnicze, żywność i paszę dla koni. Zwiększał się też ruch w gospodach, zajazdach i szynkach. Miasto czekało na przyjazd deputatów (w drugiej połowie XVII wieku 50 świeckich i ośmiu duchownych), palestry i innych urzędników, po których przybywały liczne rzesze znanej z pieniactwa szlachty. Często towarzyszyły im okazałe poczty i zastępy służby. Ważne, ale już lokalne znaczenie miały sądy ziemskie i grodzkie (szlachta powiatu lubelskiego i urzędowskiego). Polityczne znaczenie Lublina podnosił fakt, że na miejscowym zamku, a od początków XVII wieku w kościele Dominikanów, zbierały się sejmiki szlacheckie województwa lubelskiego ${ }^{12}$.

Mieszczanie opiekowali się przyjezdnymi w chorobie, zapewniali żywność, a w przypadku śmierci pogrzeb. Szlachcic Paweł Witkowski mieszkał w kamienicy spadkobierców Stanisława Poleciły przy ulicy Grodzkiej. Spisania inwentarza po zgonie gościa domagał się Piotr Podoski, który zajął się organizacją jego pogrzebu ${ }^{13}$. Zygmunt Grabia w swoim testamencie dziękował gospodarzowi, u którego się zatrzymał, za:

${ }^{10} \mathrm{~J}$. Kus, Księgi złoczyńców. O przestępcach $i$ wymiarze sprawiedliwości $w$ dawnym Lublinie, Lublin 2002, s. 45.

${ }^{11}$ R. Szczygieł, Lublin czasów renesansu i baroku. Gospodarczy, polityczny i kulturalny wizerunek miasta, „Annales Universitatis Maria Curie-Skłodowska Lublin - Polonia” sectio FF 2005, vol. 23, s. 14.

${ }^{12}$ H. Gmiterek, Lublin przed i po "potopie”, [w:] Plany i widoki Lublina XVII-XXI wiek, red. M. Harasimiuk, D. Kociuba, P. Dymmel, Lublin 2007, s. 44.

13 APL KmL, S. 138, R. 1627, Inw. Pawła Witkowskiego, s. 95. 
wszystkie jego posługi i dogody w mojej chorobie odkazuję złotych 40 [...]. Zostaje doloman perpetuowy biały, naszuwien zielony stary, welens czerwony i opońca stara biała, także i pistolet i ubranie czerwone, co ja gospodarzowi i gospodynie za pracę daruję, szablę prostą także gospodarzowi odkazuję ${ }^{14}$.

Szlachta potrafiła być hojna dla osób, które okazały się uczciwymi i gościnnymi ludźmi. Zdarzało się też, że oddawała zaprzyjaźnionym mieszczanom pieniądze i kosztowności w depozyt, tj. szlachcic Tudorowski przekazał Ewie Duracz 100 złotych w złocie ${ }^{15}$.

Szlachta goszcząca w Lublinie nie zawsze płaciła za stancje (cztery wzmianki). Kowal Andrzej Chmura wspominał, że nie zapłacono mu „od stania, ani na drwa”, więc w drodze rekompensaty, za zgodą dłużnika, odkupił należące do tegoż cztery łyżki, które były w zastawie u pani Majeranowej ${ }^{16}$. Zaskoczeni przez chorobę i pozbawieni kontaktu z najbliższymi przedstawiciele stanu szlacheckiego często decydowali się na sprzedaż koni, ubrań czy broni ${ }^{17}$.

Pod testamentami szlacheckimi wpisanymi do ksiąg miejskich wymieniana jest większa liczba świadków niż przy dyspozycjach mieszczan. Funkcję tę pełnili często lublinianie o znaczącej pozycji, np. rajcy. Na egzekutorów ostatniej woli szlachty wyznaczani byli duchowni, szlachetnie urodzeni i urzędnicy miejscy ${ }^{18}$. Niezbyt często jednak szlachta była świadkami przy spisywaniu dyspozycji mieszczan (12). Zdarzało się to np. w przypadku niektórych zamożniejszych i wpływowych obywateli miasta. Rajca Krystian Żywert wyznaczył ośmiu egzekutorów, w tym trzech przedstawicieli szlachty, z których dwóch pełniło funkcje urzędowe: pisarz grodzki i podwojewodzi lubelski ${ }^{19}$. Kiedy stosunki były bardzo życzliwe, szlachta zostawała nawet opiekunami testamentów mieszczan. Taką funkcję miał pełnić Zbigniew z Goraja Gorajski, wyznaczony przez kupca Jakuba Drossa

${ }_{14}$ APL KmL, S. 139, R. 1634, Test. Zygmunta Grabi, s. 247.

15 APL KmL, S. 138, R. 1628, Test. Ewy Duraczowej, s. 217.

16 APL KmL, S. 136, R. 1597, Test. Andrzeja Chmury, s. 276.

17 APL KmL, S. 139, R. 1634, Test. Zygmunta Grabi, s. 248.

18 APL KmL, S. 139, R. 1633, Test. Jana Tomasza Zawadzkiego, s. 51-52.

19 APL KmL, S. 168, R. 1654, Test. Krystiana Żywerta, s. 231v. 
na opiekuna ${ }^{20}$. W jednym z testamentów Gorajski, kasztelan chełmski, został nazwany „mężem wielkich cnót” ${ }^{21}$. Protektorem potomków Filemona Doroszewicza był łowczy koronny Andrzej Gniewosz ${ }^{22}$, natomiast szlachcic Daniel Iżycki, sędzia ziemski lubelski, był dla rajcy Melchiora Mężyka „dobrodziejem dawnym i protektorem jego ubogiego domu”23. Szklarz Wawrzyniec Lochyński, przyjmujący pod swój dach przyjeżdżającą do Lublina szlachtę, spisał swój testament przy pomocy jednego z jej przedstawicieli, Piotra Błędowskiego. Działo się to w obecności innych przyjezdnych:

przy tych gościech, którzy dla potrzeb swych do Lublina przyjechali, sprosiwszy ich do siebie do izby ten testament czyniłem, [...] prosiłem wszystkich Ich Mościów slachty, co przy tym byli, aby się na to podpisali ${ }^{24}$.

Szczególnie patrycjat lubelski cudzoziemskiego pochodzenia na przełomie XVI i XVII wieku stykał się z bogatą szlachtą, np. Włosi Rudgier i Daniel de Sacellis. Czynnikiem, który sprzyjał silniejszym więziom, było też uleganie nowinkom religijnym. Ewangelik Zbigniew Gorajski był protektorem wielu mieszczan tego samego wyznania, np. Jakuba Drossa i Wojciecha złotnika. Rajca Łukasz Begel mianował opiekunami żony i dzieci szlachtę: Gostomskiego z Leżenic i Stefana Snopkowskiego ${ }^{25}$. Podobną funkcję miał pełnić książę Dominik Zasławski z Ostroga, który został wybrany obrońcą testamentu przez żonę jego dawnego sługi, Katarzynę Wiśniowską ${ }^{26}$. Szlachta lubelska odgrywała dużą rolę w ruchu różnowierczym. Współpracowała też chętnie z mieszczanami, którzy przechodzili na wyznania protestanckie. Dwory szlacheckie w Lublinie były czasami miejscami, gdzie lokowano zbory.

${ }^{20},[\ldots]$ jeżeliby jaka trudność następowała będziesz WM miał wielką pomoc z Wielmożnego JMP Zbigniewa z Goraja Gorajskiego": APL KmL, S. 38, R. 1640, Test. Jakuba Drossa, s. 32v.

21 APL KmL, S. 39, R. 1642, Test. Abrahama Bomersona, s. 272v.

${ }^{22}$ APL KmL, S. 23, R. 1645, Test. Katarzyny Wiśniewskiej, s. 58.

${ }^{23}$ APL KmL, S. 23, R. 1648, Test. Melchra Mężyka, s. 81.

${ }^{24}$ APL KmL, S. 137, R. 1616, Test. Wawrzyńca Lochińskiego, s. 91.

${ }^{25}$ APL KmL, S. 137, R. 1617, Test. Łukasza Begla, s. 153.

${ }^{26}$ APL KmL, S. 23, R. 1645, Test. Katarzyny Wiśniewskiej, s. 52. 
Mieszczanie cenili sobie bardzo tzw. szlacheckie słowo i wyrażali wielkie rozczarowanie, jeśli nie zostało dotrzymane ${ }^{27}$. O jego wadze przy pożyczaniu pieniędzy wspominał w testamencie kowal Andrzej Chmura ${ }^{28}$. Słowo to liczyło się też przy zawieraniu różnego rodzaju umów, np. dotyczących najmu mieszkania ${ }^{29}$.

Dla obywateli Lublina istotne znaczenie miały przyjazne relacje z wpływową szlachtą, m.in. powiązania z urzędnikami królewskimi mogły przynosić mieszczanom wymierne korzyści. Na przykład starosta dokonywał wyboru rajcy na stanowisko burmistrza pierwszego kwartału, a wojewoda powoływał burmistrza drugiego kwartału ${ }^{30}$.

W Lublinie rozpowszechniony był też zwyczaj oddawania synów szlacheckich pod opiekę mieszczan na czas nauki w mieście. O umowie dotyczącej wynajmu mieszkania i opieki nad synem Habrama Puzowskiego wspominał w swoim testamencie Szczęsny Kwiatek:

z panem Habramem Puzowskim uczyniłem postanowienie [...] na gospodę synowi jego Janowi, który i teraz jest u mnie, miał mi dać zł. 30 liczby polskiej i legumina [...]. A czas jego skończy się w thym roku na blisko przyszłe święto Mariey Magdaleny. A thom nie wziął ani pieniędzy jednego grosza, ani legumin jednego ziarna na ten rok, który dochodzi, jeszcze swym kosztem wszystkie potrzeby jego opatruję, suknie, ubiory, czapki, buty i insze potrzeby... ${ }^{31}$

Przebywanie szlachty w mieście sprzyjało nawiązaniu bliższych więzi z miejscową społecznością, co mogło zaowocować m.in. pobytem synów mieszczańskich na dworach szlacheckich, udzielaniem im pomocy w edu-

27 Powszechnie znane było przysłowie: „Verbum nobile debet esse stabile”, czyli słowo szlacheckie musi być dotrzymane: Z. Gloger, Encyklopedia staropolska ilustrowana, t. 4, Warszawa 1985, s. 421.

${ }^{28}$ APL KmL, S. 136, R. 1597, Test. Andrzeja Chmury, s. 278.

29 APL KmL, S. 136, R. 1601, Test. Szczęsnego Kwiatka, s. 442.

${ }^{30}$ G. Jakimińska, Elita wtadzy lubelskiej gminy miejskiej w latach 1555-1651, Lublin 2012, s. 160.

31 APL KmL, S. 136, R. 1601, Test. Szczęsnego Kwiatka, s. 442. 
kacji czy karierze zawodowej ${ }^{32}$. Ławnik Wojciech Mleczko wspominał w swoim testamencie, jak podczas zarazy wyjechał z Lublina i przebywał razem z córką w domu szlachcica Pawła Węglińskiego w Mętowie. Miał żal do siebie, że nie wynagrodził gospodarzowi tej przysługi, nie gościł go w swoim domu i dlatego prosił o przekazanie szlachcicowi zapłaty ${ }^{33}$. Podobną pomoc świadczył w czasie zarazy Piasecki, podczaszy czernihowski. Ślusarz Marcin Batkowski, który schronił się do Biskupic, dziękował mu za konia i wóz, 24 kwarty gorzałki, beczkę piwa, 16 serów, garniec masła oraz pomoc przy pochówku dziecka (opłata za kopanie dołu i trumnę). Obiecywał też zwrócić poniesione koszty ${ }^{34}$.

Związki szlachty z mieszczaństwem miały m.in. podłoże finansowe. Pożyczki pieniężne udzielane szlachetnie urodzonym przez lublinian były częste (48 przypadków). Dawano je pod zastaw wartościowych przedmiotów, które szlachta decydowała się przekazać, byle tylko uzyskać potrzebne pieniądze (20 przypadków). Piotr Szuler posiadał w zastawie dwie szable złociste należące do szlachcica ${ }^{35}$. Sługa wojewody lubelskiego zastawił u mieszczki Ziarnowej półhak ${ }^{36}$. Książę Jerzy Czartoryski winien był złotnikowej Annie Lisowskiej 3 tys. zł, z tej sumy na 650 zł miała cyrograf. Także szlachcic Tarnowski był jej dłużny 400 złotych ${ }^{37}$. U przekupnia Jana Okonia szlachcianka zastawiła „złoty pierścionek z czeskim dyjamencikiem”38. Jeden z przedstawicieli szlachty dał w zastaw złotnikowi Adamowi Dachowiczowi pas srebrny pozłocisty ${ }^{39}$. Mikołaj krawiec miał u siebie w zastawie „delię czerwoną morawskiego sukna”, którą przyjął od szlachcica ${ }^{40}$. Szlachetny Szamotulski zastawił u Justyny Tesnadi szablę oprawioną srebrem ${ }^{41}$.

32 Lekarz Adam Maier liczył na to, że rodzina Zasławskich udzieli pomocy jego synowi i będzie otaczała go specjalną pomocą i protekcją: AAL, s. Rep. 60 A. 21, R. 1627, Test. Adama Maiera, k. 181v-185.

${ }^{33}$ APL KmL, S. 157, R. 1600, Test. Wojciecha Mleczko, s. 140v.

${ }^{34}$ APL KmL, S. 106, R. 1652, Test. Marcina i Anny Batkowskich, s. 509v.

35 APL KmL, S. 137, R. 1618, Inw. Piotra Szulera, s. 172.

36 APL KmL, S. 136, R. 1601, Test. Barbary Ziarnowej, s. 437.

${ }^{37}$ APL KmL, S. 138, R. 1636, Test. Anny Lisowskiej, s. 218-229.

38 APL KmL, S. 139, R. 1633, Inw. Jana Okonia, s. 118.

39 APL KmL, S. 139, R. 1636, Test. Adama Dachowicza, s. 370.

${ }^{40}$ APL KmL, S. 136, R. 1596, Test. Mikołaja Krawca, s. 224.

${ }^{41}$ APL KmL, S. 136, R. 1595, Test. Justiny Tesnadi, s. 212. 
By zaspokoić potrzeby finansowe czy usługowe, szlachta najchętniej oddawała w zastaw: broń (siedem przypadków), kosztowności (sześć), naczynia srebrne (sześć), odzież (dwa), a nawet książki (jeden). Złotnik Wojciech Kwasowicz oddał szlachcicowi wziętą w zastaw szablę, chociaż nie uzyskał pieniędzy, ponieważ zauważył, że dłużnik „nie miał z czym chodzić” ${ }^{42}$. Szabla łączyła w sobie wartości prestiżowe z demonstracją bogactwa i stanowiła nieodzowny symbol statusu społecznego ${ }^{43}$.

Lekarz Adam Maier posiadał w beczce książki należące do szlachty: Męcińskiego ${ }^{44}$, Kwiatkowskiego oraz księcia Zasławskiego ${ }^{45}$. Część z nich była podarowana Maierowi i podpisana przez księcia. Jednakże lekarz prosił, by te książki zwrócić Zasławskim ${ }^{46}$. W inwentarzu kotlarza Marcina Majchrowica znalazły się naczynia szlacheckie: „kocioł zły stary i bania stara zła z czapką [...] ta starzyzna jest szlachecka” ${ }^{37}$. U lekarza Adama Maiera szlachcic z Tarnowa zastawił następujące rzeczy: „diamentowy pierścionek mały, a drugi diamentowy [...] z łańcuszkiem, dwa lichtarze srebrne, nalewkę i miednicę srebrną" ${ }^{4}$.

Między szlachtą a częścią bogatych kupców i rzemieślników na terenie miasta istniała ożywiona współpraca gospodarcza. Przybierała ona różne formy - od zaopatrywania się w towary konsumpcyjne do usług kredytowo-pożyczkowych i lichwiarskich ${ }^{49}$. Dotyczyła też transportu rzecznego Wisłą, ponieważ na szlacheckich szkutach przewożono towary mieszczańskie, np. zakupione w Gdańsku ${ }^{50}$.

Czasami dochodziło do konfliktów mieszczan ze szlachtą. Nie zawsze bowiem spłacała ona rzemieślnikom i kupcom zaległe długi. Zmuszeni sy-

42 APL KmL, S. 23, R. 1625, Test. Wojciecha Kwasowicza, s. 7.

${ }^{43}$ A. Pośpiech, Putapka oczywistości. Pośmiertne spisy ruchomości szlachty wielkopolskiej z XVII wieku, [w:] „Studia i Materiały z Historii Kultury Materialnej”, t. 64, red. E. Balcerzak, Warszawa 1992, s. 115.

${ }^{44}$ APL KmL, S. 139, R. 1631, Inw. Adama Maiera, s. 768.

45 AAL, S. Rep. 60 A. 21, R. 1627, Test. Adama Maiera, k. 181-185v.

46 AAL, S. Rep. 60 A. 21, R. 1627, Test. Adama Maiera, k. 185.

${ }^{47}$ APL KmL, S. 139, R. 1633, Inw. Marcina Majchrowica, s. 66.

48 AAL, S. Rep. 60 A. 21, R. 1627, Test. Adama Maiera, k. 182.

49 S. Tworek, Rozkwit miasta. Renesans, [w:] Dzieje Lublina. Próba syntezy, red. J. Dobrzański, J. Kłoczowski, J. Mazurkiewicz, Lublin 1965, s. 98.

50 APL KmL, S. 138, R. 1630, Inw. Adama Rudolfowica, s. 627. 
tuacją testatorzy przekazywali pewne sumy na kościoły i szpitale, mając nadzieję, że może te instytucje będą zdolne odebrać należności od szlachty. Liczyli też na korzyści płynące $\mathrm{z}$ tych nadań w postaci modlitw i zapewnienia im lepszego pozaziemskiego bytowania. Zofia Struclina skarżyła się na swoją dłużniczkę, żonę szlachcica Chobrzyńskiego, że zwlekała z oddaniem jej długu, mimo że testatorka jeździła do niej. Posyłała w tej sprawie także księdza Kurwata - plebana targowickiego i szlachcica Pszonkę ze Strzeszkowic. Zabiegi te nie dały jednak oczekiwanego rezultatu, ponieważ szlachcianka zwlekała ze spłatą i prosiła Strucliną o cierpliwość, aż w końcu sprawa się przedawniła ${ }^{51}$. Adam Maier nie mógł pozbyć się zastawu, który wziął w Niemczech jego brat od szlachcica Andrzeja Męcińskiego z Kurozwęk. Za poręczenie brat lekarza znalazł się w więzieniu i stamtąd wykupił go Adam, który przejął również zastawione książki. Następnie przez około 12 lat procesował się ze szlachcicem w Trybunale o poniesione straty $^{52}$. Swoje książki Adam Maier pożyczył szlachcicowi Zaborowskiemu, ale prosił, aby zostały oddane jego synowi lub opiekunom ${ }^{53}$. Wśród dłużników najbogatszej warstwy mieszczan byli przedstawiciele takich rodów magnackich, jak: Koniecpolscy, Zasławscy i Wiśniowieccy. U Szymona Krawcowicza znalazło się srebro zastawione przez Samuela Koniecpolskigo, syna hetmana Stanisława Koniecpolskiego (polny koronny od 1618 roku): „miednica srebrna z nalewką białą, 2 czarki srebrne, buława srebrna pozłocista, 2 srebrne strzemiona”. Według zapewnień szlachcica szybko miano oddać pieniądze i zabrać zastawione rzeczy, tymczasem w rękach Krawcowicza były przez osiem lat, aż do jego śmierci ${ }^{54}$. Mieszczanie mieli też powiązania z członkami rodziny Koreckich (Szymon Krawcowicz, Anna Rospęcka, Stanisław Damaszewski), a złotnicy lubelscy wyrabiali dla nich biżuterię ${ }^{55}$.

Zamożna i wpływowa szlachta przysyłała do Lublina uboższych współbraci, którzy wchodzili w krąg jej klienteli i sług rękodajnych. Tu za-

51 APL KmL, S. 23, R. 1648, Test. Zofii Strucliny, s. 131.

52 AAL, S. Rep. 60 A. 21, R. 1627, Test. Adama Maiera, k. 182v.

53 AAL, S. Rep. 60 A. 21, R. 1627, Test. Adama Maiera, k. 183, 185.

${ }^{54}$ APL KmL, S. 137, R. 1616, Test. Szymona Krawcowicza, s. 71-72.

55 Zob. I. Rolska-Boruch, Cech ztotników lubelskich (XVI-XVIII w.), Lublin 1997, s. 46 . 
łatwiali w imieniu swoich chlebodawców różne sprawy urzędowe, sądowe, handlowe i towarzyskie. Patronowie natomiast płacili za ich pobyt w Lublinie i wynajęcie gospody ${ }^{56}$.

Kupcy lubelscy włączali się w szlachecki handel zbożowy. Lublin był atrakcyjnym miejscem zbytu produktów rolnych, wytwarzanych w folwarkach szlacheckich. Wysoko urodzeni przybywali do Lublina także po to, by rozliczyć się z gdańszczanami za towary spławiane Wisłą. Do handlu oferowali najczęściej większe ilości bydła, koni, zboża, nabiału, skór, futer, drewna. W mieście zaopatrywali się w różne potrzebne im przedmioty, m.in. w sukno, płótno, odzież, świece, lekarstwa, korzenie, towary kolonialne, wyroby rusznikarskie, proch strzelniczy, piwo i wino. Były wśród tych towarów książki, zakupione m.in. przez szlachcica Adama Lipskiego, który miał dług 10 zł u zamojskiego księgarza Jana Policiusa ${ }^{57}$. Mieszczka Zofia Samborczykowa ręczyła Maciejowi Kośniglowi za szlachcica Czernego, który nabył u niego ok. 12 garncy wina ${ }^{58}$. Szlachetnie urodzeni doceniali fakt, że w Lublinie były dostępne również towary luksusowe oraz szeroki asortyment wyrobów rzemieślniczych. Kupowano m.in. uzbrojenie, np. zbroje i szyszaki u płatnerza Okęckiego ${ }^{59}$. Futra, skóry i wino sprzedawał szlachcie kuśnierz Jakub Petkowski ${ }^{60}$. On i jego żona utrzymywali ożywione kontakty ze szlachtą. W aptekach wysoko urodzeni zaopatrywali się w lekarstwa i korzenie. Jan Lubomelski miał wielu dłużników spośród szlachty, która przybywała do miasta ${ }^{61}$. Aptekarz Piotr Podoski wydawał lekarstwa m.in. szlachcicowi Rabrockiemu, a on przekazał mu w zastaw „ruszniczkę srebrem nabijaną”. Natomiast inny szlachcic, Jackowski, wynajmował u niego izbę i zamiast zapłaty komornego dał w zastaw „dwa przodki rysie i pistolet zardzewiały”62. Samuel Gojski spod Sokala pożyczył

56 „JMP Tyszkiewicz wojewoda kijowski winien mi od stołu za Brześcieckiego zł. 130 i kilka"; APL KmL, S. 139, R. 1635, Test. Bartłomieja Taszkiera, s. 320.

57 APL KmL, S. 137, R. 1620, Test. Jana Policiusa, s. 370.

58 APL KmL, S. 138, R. 1630, Test. Zofii Samborczykowej, s. 493.

59 APL KmL, S. 137, R. 1620, Test. Piotra Okęckiego, s. 380.

${ }^{60}$ APL KmL, S. 136, R. 1593, Test. Jakuba Petkowskiego, s. 56-63.

${ }^{61}$ APL KmL, S. 136, R. 1596, Test. Jana Lubomelskiego, s. 233-234.

${ }^{62}$ APL KmL, S. 138, R. 1630, Test. Piotra Podoskiego, s. 496-497. 
pieniądze od krawca Wojciecha Perkowica na wydatki związane z procesami w Trybunale ${ }^{63}$.

Szlachta poszukiwała w mieście produktów o dużym stopniu przetworzenia, wymagających specyficznych umiejętności, których nie posiadali zatrudnieni niejednokrotnie w folwarkach pracownicy dworscy. Korzystała bardzo często z usług wykwalifikowanych lubelskich rzemieślników, np. złotników, ślusarzy, kowali, kuśnierzy. Powierzano im m.in. konserwację broni, pojazdów, wykonanie lichtarzy. Kontakty te były regularne w przypadku szlachty posiadającej swoje posiadłości w województwie lubelskim, np. Zasławscy, Zbigniew Gorajski, Paweł Orzechowski, Abraham Sieniuta i in. ${ }^{64}$

Mieszkańcy miast niektóre rzemiosła uważali za „lepsze”, czyli przynoszące wyższe dochody, tj. złotnictwo i kuśnierstwo. Złotnicy wyróżniali się zamożnością i ściślejszymi kontaktami ze szlachtą, duchowieństwem i patrycjatem ${ }^{65}$. Szlachetnie urodzeni byli częstym odbiorcą lubelskiego rzemiosła artystycznego ${ }^{66}$. Złotnicy wyrabiali dla szlachty m.in. pięknie zdobione rękojeści szabel, guziki ${ }^{67}$ czy srebrne lichtarze. Miecznicy wykonywali, oprawiali i ostrzyli miecze, noże, szable i inną broń sieczną oraz wyrabiali "granaty, rurały, rohatyny, czekany, siekierki, karabele, buławy" ${ }^{68}$. $\mathrm{Z}$ ich usług korzystała też okoliczna szlachta ${ }^{69}$. Szymon rymarz wymieniał w ostatniej woli „trzy skóry szlacheckie i półtorej skóry safianu brunatnego" jako surowiec znajdujący się w warsztacie ${ }^{70}$. Wyroby rymarskie często wykonywano dla szlacheckiej klienteli i stanowiły niejednokrotnie przykład wielkiego kunsztu. Szlachta zapewne często korzystała z usług kowali oraz ślusarzy, którzy zajmowali się m.in. konserwacją broni: pistoletów, rur

${ }^{63}$ APL KmL, S. 135, R. 1623, Test. Wojciecha Perkowicza, s. 38.

${ }^{64}$ Zob. J. R. Szaflik, Wieś lubelska w pierwszej potowie XVII wieku, „Rocznik Lubelski” 1960, t. 3, s. 107-128.

${ }^{65}$ Zob. I. Rolska-Boruch, Cech ztotników lubelskich (XVI-XVIII), Lublin 1997.

${ }^{66}$ Ibidem, s. 46, 73.

${ }^{67}$ APL KmL, S. 106, R. 1652, Test. Anny, s. 428.

${ }^{68}$ Dzieje Ptocka, red. A. Gieysztor, Płock 1978, s. 147; J. Kamiński, Miecznicy lubelscy, „Pamiętnik Lubelski” 1931-1934, t. 2, s. 187-217.

${ }^{69}$ J. Kamiński, Miecznicy..., s. 187-217.

${ }^{70}$ APL KmL, S. 136, R. 1593, Test. Szymona rymarza, s. 19. 
muszkietowych czy tzw. rur kobylanych. Ślusarz Maciej Pierunkowicz robił zamki do rydwanów i kłódki ${ }^{71}$.

Czasami mieszczanie skarżyli się na brak zapłaty za usługę lub towar. Zdun Maciej wspominał o piecach, które wykonał na zamku lubelskim. Zaznaczał też, że starosta nie zapłacił wynagrodzenia za jego pracę ${ }^{72}$. Szlachta niejednokrotnie odwlekała spłaty należności i zastawiała pierścień lub inny przedmiot, który z kolei potrzebujący pieniędzy rzemieślnik niósł do lichwiarza, aby choć w części odzyskać swą należność. W czasie zarazy w 1652 roku ślusarz Maciej Pierunkowicz nie oczekiwał od szlachcica zapłaty za wyroby w gotówce, lecz w żywności: „2 połcie słoniny, korzec grochu, 2 korce mąki pytlowej”. Z kolei szlachcic Przecław Czarny winien był cyrulikowi Adamowi Kwartnicznemu 2 talary lub 2 korce żyta ${ }^{73}$. Zdarzało się jednak i tak, że rzemieślnicy mieli długi wobec szlachty (osiem wzmianek), ponieważ nie zdążyli rozliczyć się z pobranych uprzednio zaliczek na wykonanie określonej pracy. Introligator Paweł Migdałowski swój dług zaciągnięty u Pszonki z Babina spłacał księgami ${ }^{74}$.

Mieszczanie znający arkana prawne często udzielali porad szlachcie przyjeżdżającej na sesje Trybunału. Sądy te odbywały się w mieście corocznie od niedzieli przewodniej do początków grudnia. Oprócz deputatów świeckich i duchownych, tj. sędziów będących przedstawicielami wszystkich województw i biskupstw z Korony, przybywały tu tłumy szlachty i magnatów (sądy gromadziły szlachtę głównie z województw: lubelskiego, krakowskiego i sandomierskiego ${ }^{75}$. W Lublinie kwitło życie towarzyskie z udziałem szlachty, która imponowała mieszczanom wielkopańskimi gestami. Na dodatkowe zarobki mogli liczyć handlarze, karczmarze, piwowarzy, a także duchowieństwo lubelskie. Często widoczne są powiązania szlachty z lubelskimi lekarzami, cyrulikami i aptekarzami. Lekarze służyli wiedzą i pomocą medyczną szlachcie przyjeżdżającej do miasta lub pozo-

${ }^{71}$ APL KmL, S. 106, R. 1652, Test. Macieja Pierunkowicza zw. Potylicki i Krystyny, s. 482.

72 APL KmL, S. 136, R. 1597, Test. Macieja Garncarza, s. 290.

73 APL KmL, S. 136, R. 1598, Test. Adama Kwartnicznego, s. 323.

74 APL KmL, S. 138, R. 1628, Test. Pawła Migdałowskiego, s. 250.

75 Zob. W. Witkowski, Trybunat Koronny w Lublinie, [w:] Spojrzenia w przesztość Lubelszczyzny, red. K. Myśliński, A.A. Witusik, Lublin 1974, s. 79-96. 
stającej w swoich domostwach w bliższej lub dalszej odległości od Lublina. Na przykład Wojciecha Oczkę łączyły z przedstawicielami tego stanu ożywione stosunki w związku z wykonywanym zawodem i wcześniejszym pobytem na dworze królewskim. Adam Maier był lekarzem książęcej rodziny Zasławskich. Miał też nadzieję, że syn będzie kontynuował zawód lekarza i utrzyma kontakty z zaprzyjaźnionym rodem:

X. Jego Mości proszę, aby Jadasia posłał na naukę do Torunia, aż fundamenta swoje będzie miał, a potem niech Xiążęciu Jego Mości służy [Aleksandrowi z Ostroga Zasławskiemu, wojewodzie bracławskiemu], bo wiem, będzie z niego za pomocą miłego Boga, dobry medik... ${ }^{76}$.

Lekarz Piotr Kliszewski obok mieszczan leczył okoliczną szlachtę, w tym magnatów, np. Firlejów. Pomogło mu to w zgromadzeniu dużej fortuny ${ }^{77}$. Ludny Lublin, odwiedzany często przez dziesiątki kupców i przewoźników towarów, a także szlachtę, stanowił znakomity teren dla praktyki lekarskiej. Wykonywanie profesji cyrulika również mogło przynosić duży dochód, ponieważ z ich usług korzystali zarówno zamożni, jak i biedniejsi mieszkańcy miasta, przyjezdni i okoliczna szlachta ${ }^{78}$.

Częste były też szlacheckie zlecenia dla lubelskich murarzy, szczególnie włoskiego pochodzenia. Moda na miejskie i podmiejskie rezydencje stała się wśród szlachty i magnaterii powszechna. Powstanie w Lublinie przed rokiem 1571 cechu muratorów, jednego z liczniejszych w Rzeczypospolitej, dało początek lokalnemu środowisku budowniczych o własnym obliczu artystycznym, zaspokajających nie tylko zapotrzebowanie miejscowe, ale swoje umiejętności i osiągnięcia przeszczepiających także na tereny ziem ruskich i Wielkiego Księstwa Litewskiego ${ }^{79}$. Środowisko lubelskich muratorów tworzyli w większości artyści obcy. W drugiej poło-

76 AAL, S. Rep. 60 A. 21, R. 1627, Test. Adama Maiera, k. 181v, $182 \mathrm{v}$.

77 M. Chachaj, Edukacja lubelskiego lekarza Piotra Kliszewskiego (zm. w 1625 r.), „Res Historica” 2004, t. 17, s. 143.

78 Zob. M. Kobylińska-Szymańska, W. Froch, Początki sztuki chirurgicznej w Lublinie i ksztatcenie jej adeptów (wiek XVI-XVIII), „Archiwum Historii Medycyny” 1980, t. 43, z. 2, s. 163-178.

79 I. Rolska-Boruch, „Domy pańskie” na Lubelszczyźnie od późnego gotyku do wczesnego baroku, Lublin 2003, s. 11. 
wie XVI wieku było ich kilkunastu, najwięcej Włochów. Do cechu należeli m.in.: Rudolf Negroni, Jakub Balin, Jakub Termanzel z Grossi, Piotr Durie, Piotr Traversi, Dominik Degre ${ }^{80}$. Mikołaj Śmigiel miał dłużników wśród szlachty, która zlecała mu prace budowlane. Wymurował m.in. dwór dla szlachcica Broniewskiego ${ }^{81}$. Jan Bielewicz, cechmistrz krawców, dysponował materiałem budowlanym i przekazał staroście Piotrowi Małachowskiemu kamień na murowanie zamku warszawskiego i ujazdowskiego ${ }^{82}$. W Lublinie szlachta podpisywała kontrakty na budowę kościołów, pałaców, dworów i kamienic ${ }^{83}$.

Niestety, negatywnie na życiu Lublina odbiły się przejazdy szlachty biorącej udział w rokoszu Zebrzydowskiego ${ }^{84}$. Chorąwie szlacheckie łupiły mieszczan, niszczyły miasto, żądając pieniędzy, podwód i żywności ${ }^{85}$. Lublinianie na ten „niebezpieczny rokoszowy” czas ukrywali gotówkę i kosztowności u zaufanych osób, np. rajców ${ }^{86}$. W 1617 roku w Lublinie znajdowało się wiele szlachty z powodu zapowiedzi przyjazdu do miasta królewicza Władysława Wazy. Mieszczanie czuli się zagrożeni zaczepkami wysoko urodzonych i unikali nocnego chodzenia po mieście ${ }^{87}$. Z podobnych przyczyn w pamięć mieszczan zapadł też rok 1569, w którym zawarto unię $e^{88}$ W trakcie takich zjazdów mieszczanie narażeni byli na różne ekscesy ze strony pijanej i butnej braci szlacheckiej.

Bardziej osobiste kontakty ze szlachtą, niezwiązane z finansami, przypadają w udziale głównie przedstawicielom lubelskiego patrycjatu. Lubli-

${ }^{80}$ I. Rolska-Boruch, „Domy pańskie”..., s. 52.

${ }^{81}$ APL KmL, S. 138, R. 1631, Test. Mikołaja Śmigiela, s. 733.

${ }^{82}$ APL KmL, S. 139, R. 1634, Test. Jana Bielewicza, s. 147.

${ }^{83}$ K. Majewski, O dziatalności kilku muratorów lubelskich z lat 1571-1625, [w:] Sztuka polska okoto roku 1600. Materiaty Sesji Stowarzyszenia Historyków Sztuki, red. T. Hrankowska, Warszawa 1974, s. 179-199.

${ }^{84}$ Szczególnie Szczęsny Herburt, przebywający w okolicach miasta po bitwie guzowskiej, najeżdżał je i niszczył, ściągając różne kontrybucje z kupców lubelskich: S. Tworek, Rozkwit miasta..., s. 96.

${ }^{85}$ M. Bogucka, H. Samsonowicz, Dzieje miast i mieszczaństwa w Polsce przedrozbiorowej, Wrocław 1986, s. 535.

${ }^{86}$ APL KmL, S. 163, R. 1621, s. 391v-392.

${ }^{87}$ APL KmL, S. 27, R. 1617, s. 334v.

${ }^{88}$ APL KmL, S. 136, R. 1597, Test. Zofii Bargiel, s. 303. 
nianie znali swoje przywileje, powiększali majątki, zdobywali wykształcenie. Mieli więc podstawy, by nie czuć się gorzej niż szlachta. Klejnot szlachecki był symbolem, któremu mogli przeciwstawiać swój znak. Gmerk mieszczański, chociaż nie nadany przez żadnego monarchę, ceniło mieszczaństwo jako znak rozpoznawczo-własnościowy o charakterze osobistym lub rodzinnym. Umieszczano go na pieczęciach, budowlach i przedmiotach użytkowych, np. kuflach ${ }^{89}$, łyżkach ${ }^{90}$, talerzach ${ }^{91}$, wyrobach cynowych $^{92}$ i srebrnych konewkach ${ }^{93}$. Służył także do oznaczania warsztatu rzemieślniczego i identyfikacji wytwórcy w przypadku wyrobu złej jakości, występując w formie cechy. W inwentarzach, wpisanych do ksiąg miejskich, odwzorowywano gmerki, aby w przyszłości rozszyfrować właściciela spisywanych rzeczy ${ }^{94}$. Przykładem może być gmerk aptekarza Adama Rudolfowicza, składający się z liter „A” oraz „R” i umieszczony na beczkach z towarem nabytym w Gdańsku" ${ }^{95}$ Kuśnierz Maciej Promnicki posiadał „łyżki z rycerzami, 6 tyżek z planetami, na których jest cecha i litery MP"96.

Zamożniejsi obywatele miejscy jeszcze w XVI wieku mogli przedostać się w szeregi szlachty poprzez koligacje i nabywanie ziemi ${ }^{97}$. Przenikanie mieszczan do stanu szlacheckiego ujawnia tytulatura przy ich nazwiskach, najczęściej typu: nobilis ac famatus... et civis Lublinensis. Określenie „szlachetny", obok honoratus, famatus, excellens, znalazło się przy kilku mieszczanach, takich jak: Rudgier de Sacellis, Daniel de Sacellis, Jan Lubomelski, Baltazar Szeligowski, Wojciech Oczko, Bartłomiej Helth. Wykonywali oni zajęcia miejskie, ale mieli też aspiracje dotyczące awansu do uprzywilejowanego stanu szlacheckiego. Wskazuje to na przejściowy charakter położenia

${ }^{89}$ „Kuflik półtorykwartowy z deklikiem połamanem z herbami nieboszczykowskimi”: APL KmL, s. 138, R. 1631, Inw. Jana Szulca, s. 731.

${ }^{90}$ APL KmL, S. 33, R. 1630, Test. Katarzyny Dresnerowej, s. 309.

91 APL KmL, S. 139, R. 1634, Inw. Jana Bielewicza, s. 165.

92 APL KmL, S. 135, R. 1644, Test. Reginy Roliny, s. 154.

93 APL KmL, S. 136, R. 1596, Test. Jana Lubomelskiego, s. 239.

${ }^{44}$ APL KmL, S. 136, R. 1593, Inw. Leonarda Mrzygłodowicza, s. 29.

95 APL KmL, S. 138, R. 1630, Inw. Adama Rudolfowicza, s. 624.

96 APL KmL, S. 138, R. 1631, Test. Macieja Promnickiego, s. 793.

97 M. Ujma, Sejmik lubelski..., s. 125. 
społecznego wspomnianych mieszczan. W inwentarzu Rudgiera de Sacellis znalazło się autentyczne świadectwo szlachectwa i jego kopia ${ }^{98}$.

Znakomitość rodów mieszczańskich podnosiły małżeństwa ze szlachtą. Można przypuszczać, że nie dochodziło do nich bez sprzeciwu rodzin z obydwu stron. W 1602 roku szlachcic Jan Rudnicki ożenił się z Barbarą, córką rajcy Sebastiana Konopnicy i Katarzyny Kretkowej, porwawszy ją uprzednio ${ }^{99}$. Barbara była bratanicą Katarzyny Rudgierowej, która w testamencie z 1619 roku wyłączyła ją od dziedziczenia majątku ${ }^{100}$. Barbara kupowała towary i zamawiała szycie ubrań u zamożnego krawca Jana Meygotha, który w swoim testamencie wspominał, że była mu dłużna ok. 700 złotych. Po śmierci Rudnickiego Barbara ponownie wyszła za mąż za szlachcica, tym razem Pawła Dziewulskiego ${ }^{101}$, a w końcu za mieszczanina Andrzeja Jeżowica ${ }^{102}$. Pochodząca z rodziny szlacheckiej Ewa Potocka była małżonką Pawła Machały, ławnika lubelskiego ${ }^{103}$. Natomiast Maciej Majer pojął za żonę Elżbietę Kłodzińską - również z rodziny szlacheckiej ${ }^{104}$. Córki Anny Krokierowej, mieszczki lubelskiej, zostały żonami szlachetnie urodzonych: Anna wyszła za Hieronima Konarskiego, a Justyna za Daniela Borzęckiego $^{105}$. Mieszczańskie kandydatki na żony miały dla szlachty niewątpliwy atut - szedł za nimi znaczny posag. Wdowy po obywatelach lubelskich także wybierały na mężów przedstawicieli szlachty. Zofia Czapla po śmierci swego małżonka, Macieja, wyszła za szlachetnego Wojciecha Pszon$\mathrm{kę}^{106}$. Wdowa po rajcy Pawle Wojsławskim poślubiła szlachcica Wojciecha Kucharskiego ${ }^{107}$. Natomiast Paweł Lasota, obywatel lubelski był krewnym

98 APL KmL, S. 136, R. 1595, Inw. Rudgiera de Sacellis, s. 209.

$99 \mathrm{Z}$. Froehlichowa, $Z$ dziejów organizacji wtadz miejskich miasta Lublina do końca XVII wieku, „Pamiętnik Lubelski” 1927-1930, t. 1, s. 91.

100 APL KmL, S. 137, R. 1619, Test. Katarzyny Rudgierowej, s. 247-248.

101 Ibidem, s. 240.

102 APL KmL, S. 139, R. 1634, Test. Jana Meygotha, s. 162.

103 APL KmL, S. 136, R. 1595, Inw. Pawła Machały, s. 198.

104 APL KmL, S. 137, R. 1617, Test. Macieja Majera, s. 101.

105 APL KmL, S. 21, R. 1603, Ordinatio bonorum Anny Krokierowej, s. 427.

106 APL KmL, S. 155, R. 1594, s. 32.

107 APL KmL, S. 137, R. 1616, Test. Doroty Sienkiewiczowej, s. 46. 
zamożnej rodziny szlacheckiej herbu Rawicz ${ }^{108}$. Jedną z dróg przejścia do stanu uprzywilejowanego był więc awans poprzez mieszane, mieszczańsko-szlacheckie związki małżeńskie, ponieważ podnosiły one prestiż mieszczan i ich rodzin.

Niektórzy lublinianie upodabniali swój tryb życia do bytu wysoko urodzonych. Byli posiadaczami nie tylko kamienic, ale również ogrodów, sadzawek, sadów i zabudowań gospodarczych, np. stodół, studni. Chętnie też poświęcali się zajęciom gospodarczym. Zamożny Szymon Krawcowicz wspominał o „sadeczku [...] własnego szczepienia”" ${ }^{109}$. Lekarz Adam Maier był właścicielem posiadłości ziemskiej, a ze względu na częste podróże miał karetę, kotczy i rydwan. Prosił, aby po jego śmierci folwark opieczętowano herbem księcia Zasławskiego, a pojazdy sprzedano ${ }^{110}$. Przytwierdzenie znaków rodowych mogło wskazywać zarządcę dóbr. Służba szlachecka przybijała też na drzwiach siedzib mieszczańskich herb lub nazwisko przyszłego rezydenta, kiedy zajmowała kwatery dla swoich szlacheckich panów na czas pobytu w mieście.

Problemem poruszanym przez szlachtę był tzw. zbytek mieszczański, czyli noszenie przez mieszczan kosztownych ubiorów, co zacierało różnice stanowe. Lubelscy patrycjusze, niezależnie od pochodzenia narodowościowego, nosili przeważnie elementy stroju narodowego, który był atrybutem szlachectwa i składał się z nieodzownego kontusza i żupana, litego pasa, obitej futrem czapki, wysokich butów i zakrzywionej „z turecka” szabli. W spisach mieszczańskich wymieniane są m.in.: żupany, kapieniaki ${ }^{111}$, giermaki, kontusze ${ }^{112}$, czamary ${ }^{113}$, a z okryć wierzchnich: szuby,

108 Zob. J. A. Wadowski, Kościoty lubelskie na podstawie źródet archiwalnych, Kraków 1907, reprint, wyd. 2, Lublin 2004, s. 27.

109 APL KmL, S. 137. R. 1616, Test. Szymona Krawcowicza, s. 58.

110 AAL, S. Rep. 60 A. 21, R. 1627, Test. Adama Maiera, k. 184-185.

111 „kapieniak karazyjowy czerwonym kirem podszyty”: APL KmL, S. 138, R. 1630, Inw. Błażeja Wilka, s. 617; „kapieniak falendyszowy lazurowy bają czerwoną podszyty”: APL KmL, S. 138, R. 1631, Inw. Filemona Doroszewica, s. 704.

112 „Kontusz falendyszowy zielony” u księgarza Bernarda Wirowskiego.

113 Na przykład „czamara czarna stara”: APL KmL, S. 139, R. 1632, Test. Mikołaja Tokarzewskiego, s. 34; Jakub Piekut kupił córce Zuzannie Bąkowej czamarę za 24 złote: APL KmL, S. 139, R. 1633, Test. Jakuba Piekuta, s. 105. 
delie $^{114}$, kurty muchajerowe ${ }^{115}$, ferezje ${ }^{116}$, kożuchy ${ }^{117}$. Spotykane są też wilczury $^{118}$. Delia - określana też jako „delura” i „ „nasuwień” - była męskim wierzchnim okryciem, długim i podbitym futrem, z rękawami. Noszono też delie krótsze, bez kołnierzy, zapinane na ozdobne guzy, a później na pętlice $^{119}$. U Marcina Batkowskiego została wymieniona delia letnia ${ }^{120}$. Rzeźnik Maciej Czapla przekazywał swoim braciom delie i żupany ${ }^{121}$. Zuzanna Dankiewicowa wspominała o zastawieniu delii szkarłatnej, przy której było „18 złotych guzów z turkusikami” ${ }^{122}$. „Delię szkarłatną aksamitem podszytą" miał też Benedykt Tesnadi ${ }^{123}$. Rudgier Sacellis, rajca lubelski pochodzenia włoskiego też ubierał się po polsku. Potwierdzają to zapisy z inwentarza, w którym spisano pozostałe po nim szaty. Wyliczono tam m.in.: czamary, giermaki, żupany, delii ${ }^{124}$. Posiadał też liczne elementy uzbrojenia, np.: puklerz żelazny, przyłbicę, dwa pancerze, siodło włoskie, miecz, dwie szpady, kord włoski, szablę oprawną w srebro, rusznicę ${ }^{125}$. Rudgier de Sacellis został pochowany „,w kołpaku rysim gładkiego aksamitu [...], do tego giermak włoski kutnorowany" ${ }^{126}$. Lubelscy mieszczanie chętnie używali dodatków do ubioru, które były uznawane za atrybuty szlachty. Były nimi takie przedmioty, jak m.in.: szabla stanowiąca składnik stroju polskiego, buzdygan

114 „Delia zielona ciemna falendyszowa podszyta lisami starymi”: APL KmL, S. 138, R. 1631, Inw. Filemona Doroszewicza, s. 704.

$115,[\ldots .$.$] kurta muchajerowa ze srebrem”: APL KmL, S. 136, R. 1600, Test. Wojciecha$ Bucifala, s. 386.

${ }^{116}$ APL KmL, S. 155, R. 1593, Test. Macieja Czapli, s. 26.

${ }_{117}$ Na przykład „kożuch popieliczy”: APL KmL, S. 136, R. 1596, Test. Katarzyny Stasienko, s. 245; „[...] kożuchów albo żupic baranich męskich 3”: APL KmL, S. 138, R. 1627, Inw. Macieja Kołygi, S. 135; APL KmL, S. 136, R. 1601, Test. Szczęsnego Kwiatka, s. 441.

${ }^{118}$ APL KmL, S. 138, R. 1629, Test. Wawrzyńca Czajkowskiego, s. 452.

119 Zob. definicję pojęcia „delia”, [w:] Wielka Encyklopedia PWN, t. 7, De ChiricoDżamdat Nasr, red. J. Wojnowski, Warszawa 2002, s. 53-54.

${ }^{120}$ APL KmL, S. 106, R. 1652, Test. Marcina i Anny Batkowskich, s. 508v.

${ }^{121}$ APL KmL, S. 155, R. 1593, Test. Macieja Czapli, s. 26.

${ }^{122}$ APL KmL, S. 139, R. 1636, Test. Zuzanny Dankiewicowej, s. 420.

${ }^{123}$ APL KmL, S. 136, R. 1599, Test. Benedykta Tesnady, s. 353.

${ }_{124}$ APL KmL, S. 136, R. 1595, Inw. Rudgiera de Sacelli, s. 207-210.

${ }^{125}$ Ibidem, s. 207-210.

${ }^{126}$ Ibidem, s. 207. 
znajdujący się np. u rajcy Molawickiego ${ }^{127} \mathrm{i}$ jedwabne pasy chętnie noszone do żupanów ${ }^{128}$. Przyjmowanie przez górne warstwy stanu mieszczańskiego stroju i zwyczajów szlachty może być dowodem na względność norm i podziałów stanowych. $Z$ drugiej strony wskazuje to na istnienie silnych wpływów kultury szlacheckiej na umysłowość i mentalność bogatych mieszczan. Przejmowali oni styl życia wysoko urodzonych, niekiedy przewyższając, nawet przepychem stroju, niezamożną szlachtę. Prawnie zastrzeżone dla szlachty futra: gronostaje, sobole i kuny zdobiły także wierzchnie stroje elity mieszczańskiej Lublina, np. Adama Maiera, Bartłomieja Kroczewicza.

Lublin był atrakcyjnym miejscem pobytu dla szlachty. W XVI wieku w obrębie murów i na przedmieściach powstawały coraz liczniej dwory szlacheckie, np. Stadnickich ${ }^{129}$ czy Piotrowskiego, z którym sąsiadowała siedziba Jana Roskowskiego ${ }^{130}$. Złotnik Jan Strowicz pozostawił swoje rzeczy we dworze Jana Konarskiego, który znajdował się między siedzibami Stadnickiego i Krzywczyńskiego ${ }^{131}$. Szlachcic Marcin Leśniowolski na początku XVII wieku wynajmował mieszkanie u mieszczan, np. u Łukasza Begla, natomiast ok. 1629 roku był już właścicielem dworu w Lublinie (przebudowany później na pałac Parysów). Osiedlanie się rodzin szlacheckich w tym ośrodku (Gorajscy, Orzechowscy, Myszkowscy, Zebrzydowscy, Szamotulscy, Sobiescy) wskazywało na wzrost handlowej i politycznej roli Lublina w XVI wieku, a nowe zabudowania przyczyniały się do upiększenia miasta ${ }^{132}$. Szlachta nabywała również kamienice w mieście: Suchodolscy, Gorajscy, Orzechowscy. Dwory na przedmieściach posiadali: Stoińscy, Urowieccy, Orzechowski, Myszkowski, Ożarowski, książę Zasławski, Pszonkowie, podkomorzy mielnicki Dębiński, kasztelan zakroczymski Lasocki. Na Podzamczu miał dwór Mikołaj Firlej, wojewoda krakowski,

127 APL KmL, S. 138, R. 1627, Inw. Jana Molawickiego, s. 79-94.

128 „Pas jedwabny, siatczany, czarny”: APL KmL, S. 136, R. 1600, Inw. Wojciecha Oczki, s. 374; „pas jedwabny czerwony i szabla z taśmą lazurową”: APL KmL, S. 106, R. 1652, Test. Wojciecha Lewickiego, s. 469v-470.

129 APL KmL, S. 135, R. 1623, Test. Reginy Richarskiej, s. 35.

130 APL KmL, S. 138, R. 1629, Test. Stanisława, s. 327-328.

131 APL KmL, S. 138, R. 1627, Inw. Jana Strowicza, s. 99-100.

${ }_{132}$ H. Zins, Lublin średniowieczny, [w:] Zarys dziejów Lublina 1317-1967, red. H. Zins, Lublin 1967, s. 15. 
na Żmigrodzie - Lubieniecki, a wojewoda wołyński na wzgórzu zw. Górą Białkowską ${ }^{133}$. W pobliżu wału miejskiego były też dwory Zamoyskiego i Koniecpolskich ${ }^{134}$.

Szlachta nabywała tu nieruchomości, aby w czasie pobytów w Lublinie zatrzymywać się we własnej siedzibie i nie szukać dla siebie oraz służby noclegu u obcych. Posiadanie takiej rezydencji podwyższało pozycję zajmowaną w ramach stanu szlacheckiego. W okresach, kiedy szlacheccy właściciele wyjeżdżali z miasta, w ich domostwach pozostawali mieszczanie - zarządcy i dzierżawcy ${ }^{135}$. Przy mniejszych posesjach utrzymywano tzw. gospodarza, przy większych dodawano parobków do pomocy. Dwór w Lublinie miał m.in. podskarbi koronny, a gospodarzami w nim byli szlachetni Zofia i Wojciech Zagórscy ${ }^{136}$. Adam Gorajski wydzierżawił małżeństwu Benedyktowi rzeźnikowi i Barbarze swój dwór na przedmieściu lubelskim ${ }^{137}$. W siedzibach urodzonych często mieszkali rzemieślnicy pracujący na potrzeby szlachty ${ }^{138}$. Osoby te raczej nie należały do cechów ${ }^{139}$. Ewa Kwiatkowa, żona sprzedawcy, przedmieszczanina, mieszkała we dworze Marka Sobieskiego, wojewody lubelskiego na $\dot{Z}$ migrodzie ${ }^{140}$, a w 1633 roku w dworku Zbąskiego przebywała małżonka szewca ${ }^{141}$. Szczególnie w czasie zarazy szlachta wyjeżdżająca z miasta oddawała swoje dwory pod opiekę mieszczan. W 1652 roku szlachcianka Kurowska wynajęła swój dwór Ka-

133 W. K. Zieliński, Monografia Lublina, t. 1: Dzieje miasta Lublina, Lublin 1878, s. $5-78$.

${ }^{134}$ L. Zalewski, Orlęta lubelskie. Nauka, wychowanie i życie mtodzieży w Lublinie 1586-1773, Lublin 1947, s. 49; zob. H. Gawarecki, O dawnym Lublinie. Szkice z przesztości miasta, Lublin 1986, s. 48, 50.

135 APL KmL, S. 139, R. 1636, Test. Doroty Kwiatkowej, s. 354.

136 APL KmL, S. 106, R. 1652, Test. Zofii Zagórskiej, s. 474.

137 APL KmL, S. 136, R. 1598, Test. Barbary, s. 327-329.

138 S. Tworek, Rozkwit miasta..., s. 85.

139 B. Mandelsberg, $Z$ dziejów gospodarczych Żydów lubelskich w pierwszej potowie XVII wieku, „Biuletyn Żydowskiego Instytutu Historycznego” 1958, s. 4.

${ }_{140}$ APL KmL, S. 138, R. 1627, Test. Ewy Kwiatkowej, s. 51.

141 APL KmL, S. 139, R. 1634, Test. Jana Bielewicza, s. 148. 
tarzynie Bobkowskiej, a Katarzyna i Sebastian Sieczka mieszkali u księcia Dominika Zasławskiego z Ostroga, wojewody krakowskiego ${ }^{142}$.

W 1649 roku wokół miasta w murach zlokalizowane były 23 jurydyki. Były to tereny prywatne, np. rodzin szlacheckich czy magnackich, oraz duchowne, np. popa ruskiego czy farna. Największą jurydyką, która znajdowała się poza zakresem władzy urzędników miejskich, było starościńskie Podzamcze, które uzyskało na przełomie XVI i XVII wieku potwierdzenie prawa magdeburskiego i odrębne sądownictwo ${ }^{143}$. Istniało tam niezależne zaplecze gospodarcze, np. cechy. Jurydyki miały własne urzędy wójtowsko-ławnicze, m.in. Podzamcze, brygidek, Prebendy św. Mikołaja, fary zw. Probostwem, augustianów, Białkowskiej Góry, Sierakowszczyzny, Słomianego Rynku ${ }^{144}$. Jurydyki zamieszkiwali głównie rolnicy i ogrodnicy, ale w związku ze zwolnieniami z opłat miejskich w jurydykach osiedlali się liczni kupcy i rzemieślnicy zw. partaczami (głównie szynkarze, szewcy i rzeźnicy) ${ }^{145}$. Wraz ze zwiększaniem się liczby jurydyk i ich znaczenia miasto $\mathrm{w}$ murach oraz powiązane $\mathrm{z}$ nim Przedmieście Krakowskie traciło na znaczeniu.

Dzięki testamentom mamy informacje o urzędnikach jurydyk lubelskich, ponieważ stosunki między obywatelami miejskimi a mieszkańcami jurydyk były częste. Ślusarz Marcin Batkowski miał wśród swoich dłużników ślusarza Tomasza Kroguleckiego, ławnika i „obywatela podzameckiego" w jednej osobie, który był mu winien 90 złotych $^{146}$. Mieszczanie utrzymywali też kontakty z obywatelami „gruntu Białkowskiej Góry przy Lublinie leżącej”. Jednym z nich był Jakub Węgrzynek, czapnik lubelski ${ }^{147}$. W obecności urzędników jurydyki na Czwartku, która należała do szlach-

${ }_{142}$ APL KmL, S. 135, R. 1652, Test. Sebastiana i Katarzyny Sieczków, s. 215; APL KmL, s. 106, R. 1652, Test. Sebastiana i Katarzyny Sieczków, s. 456.

${ }^{143}$ Archiwum Państwowe w Lublinie i jego oddziały w Chełmie, Kraśniku i Radzyniu Podlaskim. Przewodnik po zasobie archiwalnym, t. 1, red. F. Cieślak i M. Trojanowska, Lublin 1997, s. 58.

${ }^{144}$ J. Mazurkiewicz, Jurydyki lubelskie, Wrocław 1956.

145 D. Kociuba, Lublin. Rozwój przestrzenny i funkcjonalny od średniowiecza do wspótczesności, Toruń 2011, s. 133-135.

146 APL KmL, S. 106, R. 1652, Test. Marcina Batkowskiego i Anny, s. 509v.

${ }^{147}$ APL KmL, S. 106, R. 1652, s. 516v. 
ciców Niszczyckich z Radzanowa, spisał swój testament Mikołaj Ozga, mieszkaniec gruntu podległego jurysdykcji gminy miejskiej. Zezwolił na to wójt Andrzej Zaborowicz z powodu trudnych warunków atmosferycznych: „niepogody i błota” ${ }^{148}$.

Od początku XVII wieku wielu przedstawicieli szlachty postarało się o libertację od ciężarów podatkowych ich posiadłości w miastach ${ }^{149}$. W Lublinie powstawały jurydyki szlacheckie i mieszczanie mieszkający na tym terenie podlegali władzy właściciela tej ziemi. Szlachta nie przebywała stale w swoich rezydencjach, dlatego całość dworu najczęściej oddawano w czasową arendę mieszczanom lub Żydom. Część testatorów miała powiązania ze szlachtą wynikające z faktu, że zamieszkiwali na terenie jurydyk szlacheckich. Anna Błońska, mieszczka lubelska, miała dług u Marcinowej kucharzowej, która mieszkała na gruncie pani Sierakowskiej zwanym Sierakowszczyzną ${ }^{150}$. Szymon Oszecki, przedmieszczanin lubelski spisywał swój testament w domu na Przedmieściu Krakowskim, który podlegał zwierzchnictwu Zbigniewa Gorajskiego, właściciela jurydyki zwanej Gorajszczyzną $^{151}$. Wymieniony szlachcic posiadał siedzibę w podlubelskiej Czechówce i na $\dot{Z}$ migrodzie ${ }^{152}$. Wojciech Oluniewski, mieszkający dwa lata w ratuszu lubelskim, wymieniał w testamencie: „księgi gruntu WJM Pana Zbigniewa z Goraja Gorajskiego kasztelana chełmskiego", które miały wrócić do właściciela tej jurydyki ${ }^{153}$. U progu drugiej połowy XVII stulecia miasto w murach liczyło 121-125 kamienic i od sześciu do ośmiu domów drewnianych, z tego miastu podlegało 81 kamienic, reszta należała do szlachty i Kościoła. Przy Krakowskim Przedmieściu ulokowanych było 46 kamienic i 44 domy drewniane. Według ustaleń R. Szewczyka u zarania XVII wieku Lublin z przedmieściami liczył ok. 8 tys. mieszkańców, wykazując dużą dynamikę wzrostu.

148 APL KmL, S. 138, R. 1631, Test. Mikołaja Ozgi, s. 785-786.

149 W. Bondyra, Dwory szlacheckie w Lublinie w czasach saskich, „Res Historica” 2005, t. 20 , s. 188 .

150 APL KmL, S. 106, R. 1652, Test. Anny Błońskiej, s. 490.

151 APL KmL, S. 138, R. 1627, Test. Szymona Osieckiego, s. 19-20.

152 D. Kupisz, Zbigniew Gorajski (1596-1655). Studium z dziejów szlachty protestanckiej w Matopolsce w pierwszej potowie XVII wieku, Warszawa 2000, [s. 196].

153 APL KmL, S. 106, R. 1652, Test. Wojciecha Oluniewskiego, s. 450. 
Posiadanie własnej siedziby w tym mieście stało się koniecznością dla jednostek aktywnie biorących udział w życiu publicznym Rzeczypospolitej. Według lustracji z 1565 roku istniało w Lublinie zaledwie 12 dworów szlacheckich, natomiast po utworzeniu w 1578 roku Trybunału ich liczba bardzo wzrosła w mieście i na przedmieściach ${ }^{154}$. W 1602 roku liczba ta zwiększyła się do 65. Szlachta swoje siedziby lokowała głównie na przedmieściach, przyczyniając się do ich intensywnego rozwoju, ale także uniezależnienia od władz miejskich. W 1617 roku liczba dworów wzrosła do $79^{155}$. Lustracja z 1661 roku wymieniała już 72 dwory i pałace oraz 19 kamienic ${ }^{156}$.

Mieszczanie zastrzegali w ostatnich dyspozycjach, by ich majątek nie dostał się w żaden sposób w ręce szlacheckie. Piotr Trawers zapisał więc w swoim testamencie: „Aby dóbr moich stojących po mojej śmierci pozostałych żadnych prawie w obcze ręce to jest sliacheckie ku ubliżeniu prawa i prewentów miasta tego, ale tylko miejskiej condyciej [...]"157. Podobnie zaznaczano, aby wsie miejskie nie przechodziły w dzierżawę szlachty ${ }^{158}$. Nie znaczy to oczywiście, że mieszczanie w ogóle nie sprzedawali nieruchomości szlachcie. Wydaje się, że niezbyt zamożni lublinianie bez większych trudności decydowali się na takie transakcje ${ }^{159}$. Z drugiej strony kupowanie przez mieszczan dóbr ziemskich wywoływało sprzeciw szlachty ${ }^{160}$.

Niektórzy spośród szlachty, używając herbu, przyjmowali prawo miejskie i utrzymując tytuł „nobiles”, sprawowali urzędy miejskie oraz zajmowali się czynnościami kupieckimi i handlem. Taką rodziną byli Lubomelscy herbu Płomieńczyk, czyli Zadora. Zgodnie z literą prawa od 1505 roku szlachta nie mogła pracować w zawodach typowo miejskich. W związku z tym pierwszy przedstawiciel rodziny we władzach miasta, Mikołaj, prawdopodobnie herbu nie używał. Jednak jego syn, Jan, oraz wnuk, Erazm, chętnie sięgali do rodzinnych korzeni i eksponowali herb Zadora, nie tylko się nim pieczętując, ale także używając go w programie ikonograficz-

154 W. Bondyra, Dwory szlacheckie..., s. 187.

155 I. Rolska-Boruch, „Domy pańskie”..., s. 52.

156 W. Bondyra, Dwory szlacheckie..., s. 187.

157 APL KmL, S. 137, R. 1620, Test. Piotra Trawersa, s. 344.

158 APL KmL, S. 238, R. 1628, s. 520.

159 APL KmL, S. 136, R. 1594, Test. Zofii Sarninej, s. 169.

160 M. Ujma, Sejmik lubelski 1572-1696, Warszawa 2003, s. 117. 
nym, zdobiącym rodzinną kamienicę w rynku. Wysoko urodzeni czasami osiadali na stałe w mieście i prowadzili mieszczański tryb życia, niektórzy jednak po jakimś czasie powracali do stanu szlacheckiego. Wskazują na to niektóre wzmianki źródłowe. Pochodzący ze szlachty Jan Tomasz Zawadzki, złotnik był ochrzczony w kościele farnym. Tam byli pochowani jego rodzice oraz pierwsza żona. Prawdopodobnie jego matka była mieszczką, a ojciec szlachcicem ${ }^{161}$. Jeden z przedstawicieli szlachty, Augustyn Wasowski, „szlachcic z urodzenia”, w 1594 roku spisywał swój testament w Lublinie i wspominał o tym, że po okresie służby wojskowej pod rozkazami Adama Mierzejewskiego, „rotmistrza na Parnawie”, nabył tu dom i zamieszkał w nim z zaślubioną w Parnawie żoną ${ }^{162}$. Szlachcic Bartłomiej Bronicki, którego testament został spisany przed urzędem miejskim, posiadał w Lublinie m.in. dom, ogród i sad ${ }^{163}$. O swoim szlacheckim pochodzeniu wspominat w testamencie jeden z lubelskich rzemieślników, pisząc: „Ja Józef z Siestrzenicy Siestrzeński województwa i powiatu mazowieckiego, szlachcicem będąc urodzony a teraz mieszczanin, obywatel i miecznik lubelski" ${ }^{164}$.

Częste kontakty ze szlachtą stwarzały dla mieszczan możliwości zbliżenia się z grupą, której styl życia oraz pozycja cieszyły się poważaniem. Najbogatsze mieszczaństwo wiodło wystawny tryb życia, nabywało wspaniałe mieszkania, otaczało się służbą, bogato ubierało i ozdabiało drogą biżuterią. Nobilitacja szlachecka mogła być od XVII wieku ideałem życiowym mieszczanina, dlatego niektórzy patrycjusze starali się pokonać wszelkie trudności, angażując w to znaczne kapitały, aby uzyskać upragniony dokument, stawiający ich w szeregach stanu szlacheckiego ${ }^{165}$.

161 APL KmL, S. 139, R. 1633, Test. Jana Tomasza Zawadzkiego, s. 49; Być może J. T. Zawadzki spokrewniony był z Zofią Kretkówną, córka rajcy Jana, która wyszła za mąż za doktora medycyny Stanisława „Picus” Zawadzkiego, syna Stanisława rajcy krakowskiego, który był nobilitowany: Zob. G. Jakimińska, Elita..., s. 86.

162 APL KmL, S. 136, R. 1594, Test. Augustyna Wasowskiego, s. 121-122.

163 APL KmL, S. 139, R. 1637, Test. Bartłomieja Bronickiego, s. 489.

164 Biblioteka Naukowa PAU i PAN w Krakowie, s. 3262, mf. 789, Testamenty i papiery majątkowe różnych osób z lat 1564-1789, Test. Józefa Siestrzeńskiego, s. 69v.

${ }^{165}$ M. Bogucka, Miejsce mieszczanina w spoteczeństwie szlacheckim. Atrakcyjność wzorców życia szlacheckiego w Polsce XVII wieku, [w:] Spoteczeństwo Staropolskie, t. 1, red. A. Wyczański, Warszawa 1976, s. 191. 
W lubelskich kościołach odbywały się pogrzeby i pochówki szlachty. Maksymilian Młodzianowski, którego testament znalazł się między mieszczańskimi, pragnął spocząć w kościele Bernardynów po skromnym pogrzebie. Chciał być ubrany w habit bernardyński oraz przykryty czarnym suknem ${ }^{166}$. Szlachcic Mikołaj Wróblewski prosił o pogrzeb na miejscu, czyli w mieście, z mszami oraz z udziałem cechu. Pragnął skromnego pochówku, „bez żadnych ceremonii światowych”, tylko w zgrzebnej koszuli. Polecał też przygotować obiad dla ubogich ${ }^{167}$. Incydentalne w Lublinie ceremonie pożegnalne przedstawicieli stanu szlacheckiego wywierały wpływ na zwykły, można powiedzieć codzienny, a przez to nie opisywany dokładnie pogrzeb mieszczański ${ }^{168}$. W kościele Dominikanów w Lublinie znajduje się renesansowy nagrobek Mikołaja i Piotra Firlejów z 1572 roku. Jest on związany z warsztatem Jana Marii Padovany. Nagrobek Marcina Leśniowolskiego (zm. w 1628 roku) w kościele jezuickim w Lublinie należał do wyjątkowych ze względu na materiał i kompozycję. Przedstawiał postać klęczącą. Figura symbolizująca zmarłego, krzyż i emblematy rycerskie były wykonane ze srebra. Mieszczanie podziwiali szlacheckie ceremonie pogrzebowe i pochówki w kościołach, np. epitafium Wojciecha Oczki u bernardynów. Zamożni obywatele lubelscy zapewne próbowali naśladować okazalsze pogrzeby szlacheckie i magnackie, przy czym wydaje się, że często nie przekraczano granic zbytku ${ }^{169}$.

Ustanowienie siedziby Trybunału Koronnego w Lublinie w 1578 roku wpłynęło na aktywizację budownictwa mieszkaniowego, wytwórczości i lokalnego handlu oraz spowodowało rozwój życia kulturalnego i religijne$\mathrm{go}^{170}$. Posiadanie stałej siedziby w Lublinie w jakimś stopniu wiązało się z ambicjami i prestiżem, ale przede wszystkim wynikało z pragmatyzmu. Szlachcic był nie tylko ziemianinem, lecz także uczestnikiem życia publicz-

166 APL KmL, S. 137, R. 1617, Test. Maksymiliana Młodzianowskiego, s. 158.

167 APL KmL, S. 40, R. 1642, Test. Mikołaja Wróblewskiego, s. 302v.

168 Zob. S. Ochmann, Pogrzeb magnata w XVII wieku w świetle rachunków, „Acta Universitatis Vratislaviensi” 1990, t.75, nr 1108, Historia, s. 72-82.

169 A. Karpiński, Zapisy "pobożne” i postawy religijne mieszczanek polskich $w$ świetle testamentów z drugiej potowy XVI i XVII wieku, [w:] Triumfy i porażki. Studia z dziejów kultury polskiej XVI-XVIII wieku, red. M. Bogucka, Warszawa 1989, s. 222.

${ }^{170}$ D. Kociuba, Lublin. Rozwój przestrzenny i funkcjonalny..., s. 124. 
nego, zaangażowanym w życie publiczne, jeżeli nie całego kraju - to przynajmniej swego województwa czy ziemi. Wiele czasu, energii i środków poświęcał również na załatwianie spraw sądowych. Testamenty i inwentarze mieszczan wskazują, że wpływ szlachty na życie miasta w omawianym przełomowym okresie był duży. W XVII wieku zmienił się charakter ośrodka lubelskiego, a sytuacja szlachty i państwa polskiego odbijała się na pozycji mieszczan. 
